\title{
Karya Cipta Pertunjukan Wayang Perjuangan sebagai Penguatan Pendidikan Bela Negara
}

\author{
Sunardi $^{1}$, Kuwato $^{2}$, Sudarsono $^{3}$ \\ 1,2,3 Jurusan Pedalangan, Fakultas Seni Pertunjukan, Institut Seni Indonesia Surakarta, \\ Jln. Ki Hadjar Dewantara No. 19, Kentingan, Jebres, Surakarta 57126 \\ gunowijoyo@gmail.com
}

Tulisan ini mengungkap tentang pertunjukan wayang perjuangan sebagai penguatan pendidikan bela negara bagi masyarakat Indonesia. Dua persoalan penting yang dibahas yakni: (1) bentuk karya cipta pertunjukan wayang perjuangan; dan (2) fungsi pertunjukan wayang perjuangan bagi masyarakat Indonesia. Bentuk karya cipta pertunjukan wayang perjuangan dikaji dengan konsep estetika wayang, adapun fungsi pertunjukan dikupas dengan teori fungsi kesenian. Hasil pembahasan menunjukkan bahwa karya cipta pertunjukan wayang perjuangan dibangun berdasarkan beberapa unsur, di antaranya seniman, garap lakon wayang, dan boneka wayang. Pada sisi lain, pertunjukan wayang perjuangan memiliki fungsi sebagai penguatan pendidikan bela negara bagi masyarakat Indonesia.

Kata kunci: karya cipta, wayang perjuangan, pendidikan bela negara, masyarakat Indonesia

\section{The Creation Of The Wayang Perjuangan Performances As The Strengthening Of State Defense Education}

This paper reveals the wayang perjuangan performances as the strengthening of state defense education for the people of Indonesia. Two important issues are discussed, namely: (1) the form of wayang perjuangan performance; and (2) the function of wayang perjuangan for the Indonesian people. The form of wayang perjuangan studied with the aesthetic concept of wayang, while the performance function is analyzed with the theory of art function. The results of the discussion show that the works of wayang perjuangan are built based on several elements, among them artists, working on wayang plays, and puppets. On the other hand, the wayang perjuangan performance has a function as the strengthening of state defense education for the people of Indonesia.

Keywords: creation, wayang perjuangan, state defend education, people of Indonesia 


\section{PENDAHULUAN}

Dewasa ini masyarakat Indonesia berhadapan dengan krisis di berbagai bidang kehidupan, yang dimaknai sebagai rapuhnya ketahanan bangsa. Hal ini terindikasi pada lemahnya ketahanan ideologi, politik, ekonomi, sosial, budaya dan pertahanan keamanan. Memudarnya ketahanan bangsa diakibatkan oleh berbagai ancaman, baik dari dalam ataupun dari luar Indonesia. Lunturnya ketahanan bangsa ditandai dengan degradasi moral serta memudarnya rasa nasionalisme. Merebaknya korupsi, tawuran massa, terorisme, narkoba, penyimpangan seksual, dan kejahatan lainnya menjadi bukti nyata akan lunturnya ketahanan sebagai bangsa, selain adanya ancaman dari luar negeri. Oleh sebab itu, perlu adanya usaha memperkuat pilar ketahanan bangsa dengan pengajaran bela negara secara simultan bagi masyarakat Indonesia.

Bela negara menjadi kewajiban bagi setiap insan yang bernaung di dalam Negara Kesatuan Republik Indonesia. Bela negara dapat dilakukan dalam kapasitas sebagai warga negara melalui berbagai praktik positif sesuai eksistensi dan kompetensi masing-masing individu. Untuk memperkuat implementasi bela negara dari masyarakat Indonesia, salah satu upaya yaitu dengan membangun kesadaran mereka melalui pendidikan bela negara. Wahana pengajaran bela negara salah satunya dapat dilakukan melalui pertunjukan wayang. Hal ini didasari alasan bahwa daya tahan seni pertunjukan wayang yang luar biasa menjadikan wayang sebagai cultural identity, yang ditempatkan menjadi ikon budaya bangsa karena mampu mengkover dan menawarkan nilai-nilai adiluhung yang memperkuat moralitas bangsa. Kekuatan wayang telah dijadikan salah satu master piece budaya dunia oleh UNESCO (Haryono, 2009). Wayang memiliki multifungsi dalam kehidupan manusia, diantaranya sebagai wahana pendidikan budi pekerti, penyampai moralitas, pemersatu masyarakat, dan memberikan hiburan menarik bagi masyarakat.

Beberapa genre pertunjukan wayang difungsikan sebagai media pendidikan di antaranya wayang Jawa, wayang suluh, wayang pancasila, wayang babad, dan wayang perjuangan. Wayang jawa menceritakan sejarah raja-raja Jawa; wayang suluh berisikan program pemerintah seperti $\mathrm{P} 4, \mathrm{~KB}$, transmigrasi dan sebagainya; wayang pancasila memuat ajaran mengenai dasar negara Indonesia; dan wayang perjuangan mengangkat kisah tentang perjuangan para pahlawan Indonesia melawan penjajah (Mulyono, 1975). Genre wayang ini tidak mampu berkembang di masyarakat karena kemasan yang kurang menarik, ceritanya monoton, serta sifatnya sangat menggurui. Fenomena ini memberikan stimulan signifikan untuk menyusun karya cipta pertunjukan wayang perjuangan dalam perspektif baru sebagai sarana untuk menyampaikan pendidikan bela negara bagi masyarakat Indonesia.

Karya cipta pertunjukan wayang perjuangan didasari pada konsep garap pertunjukan wayang, yakni: (1) lakon yang disajikan adalah perjuangan tokoh besar bangsa, seperti Jenderal Sudirman, Bung Tomo, dan lain-lain; (2) bahasa yang dipergunakan yakni bahasa Indonesia agar mampu diterima masyarakat di seluruh Indonesia; (3) gerak ( $s a$ bet) wayang disusun dengan menarik menerapkan repertoar gerak yang atraktif dan bermakna; (4) musik dirancang dengan aransemen yang menarik menggunakan alat musik tradisional dan modern; (5) tata lampu disusun untuk memperkuat suasana dan peristiwa lakon yang dipergelarkan, dengan penggunaan lampu multiwarna; (6) penggunaan sound effect untuk memperkuat estetika pertunjukan wayang perjuangan; dan (7) penciptaan boneka wayang yang merepresentasikan tokoh-tokoh pejuang Indonesia dalam stilasi figure wayang.

Atas dasar pemikiran tersebut perlu dipaparkan dua persoalan yakni (1) bagaimana bentuk karya cipta pertunjukan wayang perjuangan; dan (2) bagaimana fungsi pertunjukan wayang perjuangan bagi masyarakat Indonesia.

\section{SEKILAS TENTANG GENRE PERTUNJUKAN WAYANG PERJUANGAN}

Dalam sejarah pertunjukan wayang Indonesia, ditemukan bukti perkembangan wayang yang difungsikan sebagai wahana perjuangan bangsa. Sri Mulyono mengidentifikasi beberapa genre pertunjukan wayang berbasis cerita perjuangan, seperti wayang Jawa, wayang suluh, dan wayang perjuangan. Wayang Jawa mengangkat tema perjuangan bangsa Jawa melawan penjajah, seperti tercermin pada lakon Perang Diponegoro; wayang suluh memfokuskan pada persoalan perjuangan bangsa Indonesia yang disampaikan kepada khalayak, dan wayang perjuangan berisikan mengenai sepak terjang perjuangan para pahlawan bangsa Indonesia (1982:162-163). Intinya, wayang dengan cerita perjuangan dipergunakan sebagai propaganda dan pengajaran bela negara bagi masyarakat Indonesia.

Di antara berbagai genre wayang tersebut yang paling terkenal adalah wayang suluh dengan cerita perjuangan mengusir penjajah Belanda (Soetarno dkk, 2007:133). Jika dicermati, sejarah wayang suluh telah dimulai pada tahun 1920, jauh sebelum kemerdekaan Indonesia. Kemunculannya bermula dari proses kreatif yang dilakukan R.M. Soetarto Hardjowahono asal Surakarta yang membuat wayang untuk cerita-cerita yang realistik sifatnya, bukan cerita epos Ramayana dan Mahabarata seperti lazimnya wayang kulit Jawa. Ciri khas wayang suluh dapat diperlihatkan pada bentuk boneka wayang sebagai representasi figur manusia, terutama tokoh-tokoh yang terlibat dalam perjuangan melawan penjajah. Oleh karena lakon yang dipentaskan terkait dengan cerita realitis atau kisah keseharian manusia maka dikatakan sebagai wayang sandiwara, selanjutnya dinamakan wayang perjuangan karena tokoh dan peristiwa yang ditampilkan terkait perjuangan bangsa Indonesia.

Pada masa perlawanan terhadap penjajah, orang-orang yang tergabung Generasi Baru Angkatan Muda RI dan 
Badan Konggres Pemuda RI di Madiun tahun 1947 mencoba menciptkan wayang suluh sebagai media perjuangan. Menurut Sri Mulyono, wayang suluh dibuat oleh Jawatan Penerangan sebagai sarana penerangan mengenai perjuangan masa perang kemerdekaan Republik Indonesia (1982:162). Wayang suluh telah lepas dari tradisi pedalangan klasik dan dirasa cukup representative untuk memberikan penerangan mengenai dasar dan tujuan perjuangan bangsa Indonesia. Penyebutan wayang suluh, karena fungsi utama pertunjukan wayang ini sebagai wahana penerangan atau penyuluhan kepada masyarakat, dalam hal ini makna kata suluh adalah penerangan. Pertunjukan wayang suluh untuk tujuan perjuangan kemerdekaan, pertama kali diselenggarakan pada 10 Maret 1947 di Madiun Jawa Timur. Pada waktu itu hadir beberapa perwakilan partai dan wakil Kementerian Penerangan Yogyakarta. Ketika pergelaran berlangsung diadakan sayembara untuk menetapkan pemberian nama genre wayang tersebut. Hasilnya, wayang ini diberi sebutan wayang suluh, yang sebelumnya juga bernama wayang merdeka.

Pertunjukan wayang suluh menggunakan musik berupa gamelan yang disenangi oleh masyarakat pada masa itu. Syair lagu yang digunakan adalah lagu-lagu klasik serta lagu menurut jamannya, seperti: Selabinta, Pasir Putih, Mars Pemuda, Sorak-sorak Bergembira dan sebagainya. Adapun lakon-lakon yang dipertunjukkan digubah berdasarkan beberapa kejadian penting pada masa revolusi kemerdekaan Indonesia. Lakon-lakon yang seringkali dipergelarkan, yaitu: Sumpah Pemuda, Proklamasi Kemerdekaan, Perang Surabaya 10 Nopember, Sang Merah Putih, Perjanjian Linggarjati, Perjanjian Renville dan lainnya. Maka dari itu pertunjukan wayang suluh menampilkan tokoh-tokoh pejuang bangsa Indonesia seperti: Bung Karno, Bung Hatta, Syahrir, Agus Salim, Mangunsarkoro, Sam Ratu Langi, Wolter Monginsidi, Van Mook, Van der Plash, Jenderal Spoor dan sebagainya (Sunardi dkk, 2016:7-10). Claire Holt mencatat bahwa wayang suluh menggambarkan para pemimpin Indonesia, para pejabat, militer, serta tokoh-tokoh sipil. Selain itu terdapat tokoh yang merupakan musuh bangsa Indonesia yaitu wakil pemerintahan Belanda, serta orang-orang asing yang menengahi persoalan kemerdekaan yang merupakan wakil Perserikatan Bangsa-Bangsa (2000:159).

Mengenai wayang perjuangan atau wayang revolusi, yang dulunya bernama wayang perdjoengan telah diciptakan oleh Raden Mas Sayid dariMangkunegaran Surakarta. Tujuan penciptaan adalah untuk membangkitkan semangat perjuangan bangsa Indonesia. Wayang perjuangan ini dibeli dan disimpan di Wereldmuseum di Rotterdam, Belanda. Pada tahun 2005 wayang ini dikembalikan ke Indonesia serta disimpan di Musem Wayang Jakarta dengan penggantian nama menjadi wayang revolusi. Wayang suluh dan wayang revolusi dengan mengangkat tema perjuangan kemerdekaan Indonesia menjadi sumber inspirasi untuk penyusunan karya cipta pertunjukan wayang per- juangan dengan nuansa kebaharuan, baik dalam kemasan pertunjukan, teknik penyajian, lakon wayang, dan figur boneka wayang. Karya cipta pertunjukan wayang perjuangan inilah yang merupakan revitalisasi dari wayangwayang tema perjuangan yang telah ada di Indonesia. Pada dasarnya pertunjukan wayang perjuangan dijadikan sebagai wahana penguatan pendidikan bela negara bagi masyarakat Indonesia.

\section{ESTETIKA KARYA CIPTA PERTUNJUKAN WAYANG PERJUANGAN}

Estetika pertunjukan wayang perjuangan diketahui dari elemen pembentuknya. Kajian estetik dapat mengarahkan analisisnya pada seniman pengkarya, obyek pertunjukan, ataupun penghayatan pertunjukan (Parker, 1948:20). Pada pembahasan ini akan difokuskan pada tiga unsur yaitu seniman sebagai pelaku utama pertunjukan, lakon wayang yang dipertunjukkan, dan boneka wayang sebagai pemeran watak tokoh dalam pertunjukan. Antara seniman, lakon wayang, dan boneka wayang menjadi kesatuan integral dalam membentuk keindahan karya cipta pertunjukan wayang perjuangan. Pertunjukan wayang pada umumnya menempatkan kedudukan dalang sebagai tokoh sentral memegang kendali utama bagi tercapainya derajat estetik pertunjukan wayang. Dalam jagat pewayangan Jawa, kata 'dalang' diinterpretasikan berdasarkan arti yang diberikan yaitu: 'yang berkelana' yang memberikan pemahaman seorang pemain yang berkeliling (Holt, 2000:178). Oleh Hazeu diterangkan mengenai hubungan antara perkataan 'dalang' dengan 'langlang' yang berarti menjelajah, mengembara, mengingatkan pada kata ambarang wayang, yang artinya berjalan dari tempat satu ke tempat lain untuk mempertunjukkan wayang (1987:10). Masyarakat Jawa memandang bahwa dalam kesusasteraan Jawa, kata 'dalang' berasal dari wédha dan wulang, diartikan sebagai orang yang bertugas mengajarkan nasihat mengenai tafsir weda kepada penontonnya. Kata 'dalang' juga dapat dimaknai dari kata ngudhal piwulang, yaitu orang yang memberikan ajaran atau nasihat kebaikan bagi pendidikan moralitas manusia (Jazuli, 2003:13).

Dalang dalam pertunjukan wayang perjuangan merupakan orang yang memainkan boneka wayang dalam ujaran maupun gerakan wayang, mengendalikan musik pertunjukan, melantunkan sulukan (nyanyian dalang), serta menciptakan suasana adegan sesuai lakon yang dipresentasikan. Artinya bahwa dalang dalam karya cipta pertunjukan wayang perjuangan menjadi tokoh kunci di dalam mewujudkan tercapainya derajat estetik pertunjukan wayang. Estetika lakon, gerak, antawecana, dan sulukan dapat diwujudkan dengan baik karena kekuatan dalang serta adanya dukungan dari komponen pertunjukan lainnya, seperti pengrawit, pesinden, penggerong, dan sulih suara.

Pada pertunjukan wayang, pekerjaan dalang dibantu oleh seniman lainnya yang bertugas memainkan musik gamelan, yaitu pengrawit. Dalam pemahaman masyarakat 
Jawa, pengrawit seringkali dinamakan niyaga, pradang$g a$, atau musisi. Jumlah pengrawit dalam setiap pertunjukan wayang kulit, antara 15 sampai 30 orang, bahkan lebih, disesuaikan dengan kebutuhan. Orang yang bertugas menyajikan vokal putri atau sindhènan dinamakan sebagai pesinden. Selain pesinden, dalam pertunjukan wayang juga memerlukan penggerong yang fungsi utamanya adalah hampir sama dengan pesinden. Seniman lain yang memberikan dukungan signifikan bagi pertunjukan wayang perjuangan adalah sulih suara. Sulih suara merupakan orang yang bertugas mengisi suara, baik untuk kepentingan narasi ataupun dialog tokoh wayang. Sulih suara terdiri dari laki-laki dan perempuan yang memerankan tokoh wayang yang ditampilkan dalam suatu lakon. Berbeda dengan pertunjukan wayang pada umumnya yang didominasi dalang dalam dialog dan narasi wayang, pada pertunjukan wayang perjuangan kedudukan dalang dalam hal ini digantikan oleh sulih suara. Sulih suara sangat memahami karakter tokoh dan suasana adegan yang ditampilkan dalam pertunjukan wayang perjuangan.

Sinergi antara dalang, pengrawit, pesinden, penggerong, dan sulih suara akan mendukung tercapainya kualitas estetika pertunjukan wayang perjuangan. Konsep terpadu, yakni persatuan antara kualitas dalang dan seniman pendukung lainnya akan mampu mempresentasi lakon wayang secara hidup dan menjiwai. Estetika pertunjukan wayang perjuangan dihasilkan dari sekumpulan kreativitas dan daya tafsir dari seniman pendukung pertunjukan.

Bangunan estetika pertunjukan wayang perjuangan juga didukung oleh keberadaan musik atau karawitan serta unsur pendukung lainnya, yaitu panggung (kelir), tata lampu, dan tata suara. Instrumen musik yang digunakan adalah gamelan dan dapat ditambah beberapa instrumen musik lain, seperti biola, drum, dan cymbal. Adapun vokabuler gending ataupun lagu yang dimainkan adalah repertoar gending klasik, susunan baru, maupun lagu-lagu perjuangan. Intinya, musik dan lagu yang dibawakan memberikan dukungan yang signifikan bagi tercapainya kualitas estetik pertunjukan wayang perjuangan. Tata lampu dan tata suara juga memberikan dukungan estetik dalam mempresentasikan lakon wayang perjuangan.

Karya cipta pertunjukan wayang perjuangan didasarkan pada konsep estetika, yang meliputi konsep lakon, konsep boneka wayang, konsep musik, dan konsep antawecana. Dalam pandangan umum, istilah lakon seringkali disamakan dengan cerita, sehingga lakon wayang adalah cerita wayang itu sendiri. Lakon berarti kisah yang didramatisasi dan ditulis untuk dipentaskan para pemain di depan penonton. Lakon wayang secara umum dapat ditempatkan pada dua ranah yaitu ide dan implementasi dalam pertunjukan. Perspektif dramaturgi menyatakan bahwa lakon terdiri atas struktur dan tekstur. Pada pemahaman lain lakon dimaknai sebagai sanggit dan garap pertunjukan wayang (Sugeng Nugroho, 2012). Dalam pertunjukan wayang perjuangan, lakon pada awalnya diwujudkan dalam teks naskah yang merupakan orientasi utama di dalam penggarapan unsur pakeliran, seperti antawecana, sabetan, dan vokal-instrumentalnya.

Penyusunan lakon wayang perjuangan bersumber dari sejarah perjuangan para pahlawan bangsa Indonesia. Sejarah perjuangan ini telah banyak dibukukan oleh para penulis terdahulu, terutama yang mengupas tentang liku-liku perjuangan Jenderal Soedirman dalam merebut dan mempertahankan kemerdekaan Indonesia. Namun demikian, dalam berbagai sumber pustaka belum ditemukan alur perjuangan Jenderal Soedirman dan berbagai konflik yang menyertainya dalam format cerita atau lakon, terutama yang dikemas dalam pertunjukan wayang.

Lakon dalam pertunjukan wayang perjuangan digubah dengan menerapkan struktur besar seperti pada lakon wayang kulit purwa, yakni bagian pathet nem, bagian pathet sanga, dan bagian pathet manyura. Namun demikian pada tiap bagian ini tidak secara persis mengikuti struktur lakon tradisi yakni berbegai adegan yang telah dibakukan, namun menyesuaikan kebutuhan cerita. Dengan demikian pada tiap bagian memuat beberapa adegan yang dirasakan sangat signifikan mengungkap perjuangan Jenderal Soedirman. Pada dasarnya pertunjukan wayang adalah presentasi lakon oleh seniman dalang yang didukung pengrawit, pesinden, penggerong, dan sulih suara. Pertunjukan wayang perjuangan, lakon yang dipilih adalah tema perjuangan para pahlawan dalam merebut dan mempertahankan kemerdekaan Indonesia. Pada pertunjukan wayang perjuangan ini, lakon yang dipaparkan yaitu "Gerilya Jenderal Soedirman". Lakon ini menceritakan mengenai sepak terjang perjuangan Panglima Besar Jenderal Soedirman untuk mempertahankan negara Indonesia. Siasat perang gerilya menjadi spirit perjuangan Jenderal Soedirman dalam menghadapi gempuran tentara Belanda. Perjalanan panjang Jenderal Soedirman dimulai dari Keraton Yogyakarta menuju daerah pegunungan di Yogyakarta, Jawa Tengah, bahkan hingga Jawa Timur dan kembali lagi ke Yogyakarta. Semangat perjuangan Jenderal Soedirman menjadi teladan bagi negarawan dan masyarakat Indonesia untuk selalu mencintai bangsa dan negara dari berbagai gangguan.

Konsep struktur lakon Gerilya Jenderal Soedirman terdiri atas tiga bagian besar yang terdiri dari beberapa adegan yang menunjukkan liku-liku perjuangan Panglima Besar Jenderal Soedirman. Pada bagian pathet nem, terdapat adegan mengenai kelahiran Soedirman hingga kejayaan Soedirman pada perang Ambarawa; peristiwa bom Jogja yang ditindaklanjuti Soedirman dengan siasat perang gerilya menuju desa dan pegunungan dari Yogyakarta, Jawa Tengah, dan Jawa Timur. Pada bagian pathet sanga, diuraikan berbagai adegan yaitu: penyamaran Jenderal Soedirman sebagai Kyai sampai dirinya mengumumkan semangat perang gerilya di stasiun radio peninggalan Jepang untuk membangkitkan semangat perjuangan tentara 
Indonesia. Pada bagian akhir yakni pathet manyura diceritakan mengenai penderitaan Soedirman di tengah hutan karena dikepung Belanda hingga mampu meloloskan diri bersama pengawalnya, kisah Abdulah Lelonoputro, hingga kembalinya Soedirman ke istana Yogyakarta.

Pada penyajian lakon wayang, terdapat konsep estetika yang mendasarinya, yakni konsep mungguh dan konsep nuksma. Konsep mungguh mengindikasikan adanya pola hubungan harmoni antara berbagai unsur garap pertunjukan wayang perjuangan, seperti garap narasi dan dialog, garap gerak wayang, dan garap musik wayangnya. Adapun konsep nuksma diartikan bahwa penyajian lakon wayang dapat dilakukan secara hidup dan menjiwai, seperti dramatisasi, gerakan wayang, dan lagu vokal maupun instrumentalnya. Dalam pandangan Sunardi (2014), konsep mungguh dan nuksma menjadi orientasi estetik dari pertunjukan wayang.

Di dalam pergelaran wayang kulit, boneka wayang memiliki kedudukan sebagai visualisasi pemeran watak tokoh. Oleh karena pergelaran wayang kulit menggunakan benda mati, yaitu boneka wayang, sebagai pemeran watak tokoh, maka dibantu oleh dalang untuk menghidupkan peran tersebut, melalui antawecana dan gerak gerik boneka wayang. Boneka wayang dibuat dari bahan dasar kulit kerbau yang telah dibersihkan bulunya serta dikeringkan. Kulit yang dipilih, benar-benar kulit yang telah kering dan memiliki ketebalan rata-rata, tidak melengkung, serta tidak cacat. Untuk menghasilkan pahatan yang lebih baik, maka dipilih kulit kerbau yang masih muda, selain itu kerbau yang berpenyakit kurap juga menghasilkan kualitas kulit yang lebih baik karena kadar lemak yang dikandung sangat rendah (Haryanto, 1997:39).

Boneka wayang perjuangan didesain berdasarkan tokoh-tokoh sesungguhnya yang telah distilisasi dalam bentuk wayang kulit. Konsep penyusunan boneka wayang perjuangan yakni memadukan figur wayang purwa dengan manusia sehingga menghasilkan bentuk wayang dengan raut muka manusia dipadukan dengan bagian bawah (sorsoran) wayang purwa. Perpaduan ini memperhitungkan proporsional bentuk tubuh dan raut muka wayang serta penambahan asesoris wayang, seperti sumping, kalung, gelang dan sebagainya. Atas dasar konsep perpaduan antara wayang purwa dengan gambaran manusia realistik menghasilkan corak baru boneka wayang perjuangan. Bentuk boneka wayang perjuangan ini memiliki perbedaan mendasar dengan beberapa boneka wayang lainnya, seperti wayang suluh, wayang dupara, wayang babad pesisiran dan sebagainya.

Berdasarkan posisi peran di dalam lakon wayang perjuangan, terdapat penggolongan tokoh dalam dua kubu, yakni golongan tokoh pejuang dan golongan tokoh penjajah. Golongan pertama terdiri atas para pejuangan bangsa yang bertekad mempertahankan kemerdekaan dan berusaha mengusir Belanda. Para tokoh pejuangan di antaranya:
Jenderal Soedirman, Soekarno, Moh. Hatta, Cokro Pranolo, Supardjo Rustam, dr. Suwondo, Heri Kesser, Utoyo Kolopaking, Hanum, Pak Lurah, Bu Lurah, Abdulah Lelonoputro, Bu Dirman, Tidarwono, Roto Suwarno, Gatot Subroto. Adapun para tokoh penjajah terdiri atas tentara Belanda, Jenderal Spoor, para pimpinan Belanda, termasuk di dalamnya para pribumi yang menjadi mata-mata Belanda.

Estetika boneka wayang, selain diperlihatkan melalui wujud fisik atau visualnya, seperti tatahan dan sunggingan, juga dapat diperlihatkan melalui gerak-gerik tokoh wayang atau dikenal dengan konsep sabetan wayang. Sabetan wayang atau sabet (dalam wayang purwa) ditelusuri dalam beberapa ragam, seperti cepengen, tancepan, bedholan, solah, dan entas-entasan, yang dapat diamati pada berbagai vokabuler dan makna gerak. Cepengan diartikan sebagai teknik dalang dalam memegang boneka wayang (Murtiyoso dkk, 1984:82). Orientasi cepengan yang dilakukan oleh dalang bertumpu pada gapit (tangkai wayang) yang letaknya di bawah kaki belakang dari boneka wayang. Estetika cepengan diindikasikan dari kepiawaian dalang dalam memegang wayang atau cek dadi, yang berarti sekali pegang langusung dapat dimainkan dengan hidup dan menjiwai. Selain itu, terdapat konsep tancepan yang merupakan sistem pencacakan boneka wayang pada gedebog yang dibingkai kelir. Tancepan memberikan tampilan estetika yang menggambarkan adegan dengan tokoh, suasana, dan tempat tertentu sesuai lakon wayang yang disajikan. Konsep estetika tancepan terdiri atas tancepan kontras, simetris, asimetris pada satu bingkai adegan wayang dalam pertunjukan. Solah diartikan sebagai gerak-gerik tokoh wayang dengan orientasi pada penjiwaan tokoh atau urip. Gerak wayang yang estetik adalah gerakan yang hidup dan menjiwai atau nuksma dan mungguh sehingga diperlukan pemahaman mengenai solah yang pilah, cetha, dan krasa atau memiliki kejelasan makna. Pilah bermakna bahwa gerak yang ditampilkan bervariasi serta memiliki spesifikasi tersendiri. Cetha memiliki arti bahwa gerakan tokoh wayang dibuat dengan jelas atau merepresentasikan gerakan tertentu secara jelas. Adapun krasa berarti gerak-gerak yang ditampilkan dapat terasa hidup dan menjiwai sesuai karakter tokoh, suasana hati, peristiwa, serta suasana adegan.

Musik wayang perjuangan menggunakan instrumen gamelan yang berfungsi sebagai penguat suasana adegan dan suasana batin tokoh pada pertunjukan lakon wayang. Oleh karena menggunakan instrumen gamelan, maka repertoar gending-gendingnya disesuaikan dengan kebutuhan garap lakon. Secara estetis musik wayang perjuangan akan memberikan bingkai bagi tiap-tiap adegan yang ditampilkan. Repertoar gending yang dipilih dapat bersumber dari gending tradisional klasik ataupun garapan baru. Pola gending yang digunakan yaitu ladrang, ketawang, gending, ayak-ayak, srepeg, sampak, dan kemungkinan pola lain yang sengaja disusun. Pola atau bentuk gending ini 


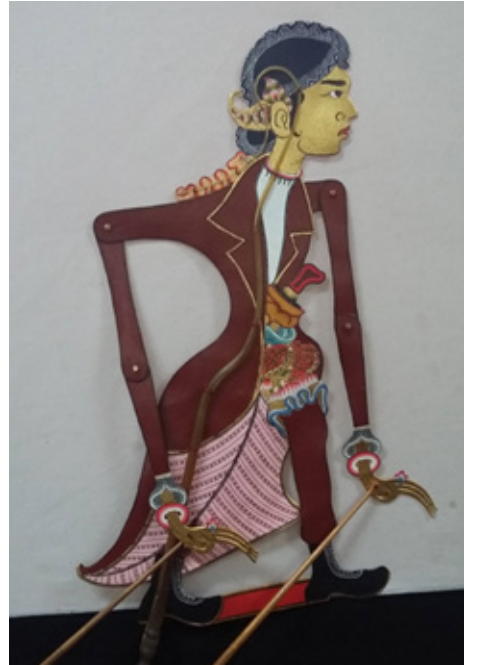

Gambar 1. Tokoh Jenderal Soedirman (sumber: Sunardi, 2017)

juga mengikuti adegan yang ditampilkan sehingga dapat mendukung dan memberikan penguatan peristiwa atau suasana dalam lakon yang digelar. Adegan sedih menggunakan gending dengan nuansa sedih pula (tlutur); adegan agung akan menggunakan gending dengan nuansa agung dan sebagainya. Ini artinya pertimbangan harmoni antara rasa adegan dengan rasa musikal menjadi tuntutan utama garap musik wayang perjungan.

Secara umum, terdapat konsep estetika musik wayang perjuangan yang mengacu pada musik wayang purwa atau karawitan pakeliran, yaitu konsep mungkus dan nglambari (Waridi, 2005). Konsep mungkus mengindikasikan bahwa musik wayang membingkai peristiwa, suasana adegan, maupun situasi batin tokoh. Di sini terjadi sinergi kuat antara gerak dan antawecana wayang dengan musik pengiringnya. Konsep nglambari dalam musik wayang diperlihatkan bahwa musik memiliki kedudukan memperkuat terciptanya penggambaran peristiwa, suasana adegan, dan situasi batin tokoh wayang.

Konsep estetika musik pada pertunjukan wayang perjuangan lebih kepada konsep mungguh atau harmoni, yaitu terjadinya keselarasan antara aspek musikal dengan adegan yang dipergelarkan. Penggunaan gending dengan nuansa sedih, gembira, semangat, agung, merdeka, asmara, dan sebagainya bersinergi dengan adegan yang ditampilkan. Konsep harmoni ditunjukkan dari adanya keselarasan antara adegan, tokoh, peristiwa, suasana hati tokoh, gerak, dialog, narasi, antawecana dengan musik wayang perjuangan.

Pada penyajian pertunjukan wayang perjuangan, selain menggunakan gending sebagai penguat rasa estetik, juga dipergunakan sulukan, tembang, dan dhodhogan-keprakan. Sulukan atau nyanyian dalang serta tembang memberikan penekanan dan penguatan dalam mendramatisasikan adegan wayang perjuangan. Sulukan ada-ada, sendhon,

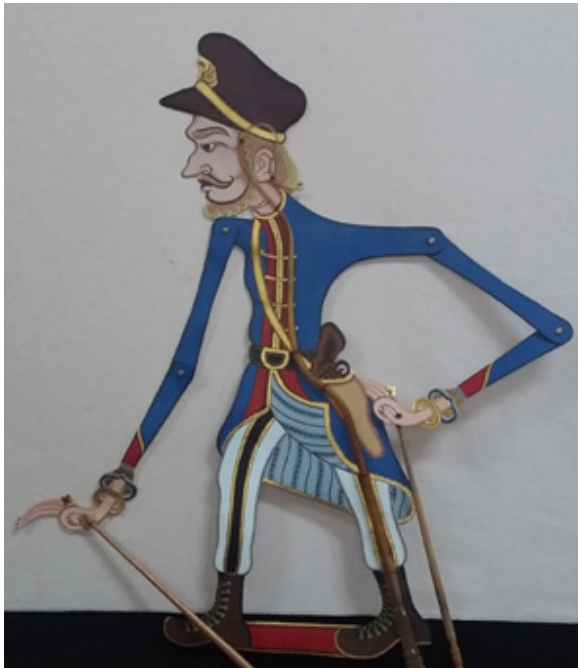

Gambar 2. Tokoh Jenderal Spoor (sumber: Sunardi, 2017)

dan pathetan dipilih dengan menyesuaikan nuansa rasa adegannya. Adegan bersemangat dipergunakan sulukan ada-ada greget saut untuk membangkitkan rasa semangat. Demikian pula dengan sulukan sendhon untuk suasana sedih ataupun ragu, serta sulukan pathetan untuk suasana agung atau merdeka.

Tembang yang dilantunkan pesinden ataupun pengerong diharapkan akan memberikan variasi nuasa rasa musikal sehingga tercipta suatu penyajian pertunjukan wayang perjuangan yang estetis. Tembang tradisonal dan tembang-tembang dengan tema perjuangan akan mewarnai penyajian pertunjukan wayang perjuangan. Hal lain yang perlu diperhatikan adalah dhodhogan-keprakan yakni bunyi instrumental cempala dan keprak yang difungsikan untuk memberikan penekanan pada musik wayang perjuangan. Mengenai musik wayang perjuangan di antaranya adalah: Ada-ada Kinanthi, Sampak Kebumen, Srepeg Mataraman, Ladrang Teguh Jiwa, Ladrang Prabu Dewa, Srepeg Nyamat, Ladrang Sarayuda Srepeg Lanjari, dan sebagainya.

Ekspresi wacana verbal pada narasi dan dialog tokoh wayang yang dilakukan dalang dalam pertunjukan wayang dinamakan antawecana. Antawecana menekankan daya ekspresi pada aspek suara dalang, sehingga suara menjadi basis pencapaian nuansa estetik. Ekspresi dialog dan narasi dalam pertunjukan wayang perjuangan dapat tercapai ketika dalang telah memiliki endapan pengalaman jiwa mengenai berbagai dialog tokoh dan narasi suasana atau situasi batin tokoh. Pengalaman jiwa yang berhubungan dengan dialog berbagai suasana dan narasi berbagai peristiwa diolah secara kreatif oleh dalang sehingga memunculkan berbagai dialog dan narasi dalam pertunjukan wayang. Dalam mengekspresikan dialog wayang, dalang mengandaikan dirinya seolah-oleh menjadi tokoh yang diwacanakan. Dengan demikian, pikiran, perasaan, emosi, dan tabiat wayang telah dikuasai oleh dalang dan diekspresikan 
dengan tepat. Hal ini juga berlaku untuk pengekspresian narasi wayang, dimana seorang dalang melibatkan diri dalam berbagai suasana atau peristiwa yang tengah terjadi.

Pengekspresian dialog tokoh sangat tergantung berbagai hal, seperti: figur tokoh, watak tokoh, suasana hati tokoh, persoalan yang dibicarakan. Dalam hal figur tokoh, ekspresi dialog sangat mempertimbangkan warna antawecana, seperti tokoh puteri dengan ekspresi antawecana dengan suara wanita; tokoh alusan diekspresikan dengan warna antawecana halus; tokoh bapang dengan warna suara mantap; dan tokoh Belanda dengan suara keras kasar; dan sebagainya. Ekspresi dialog berdasarkan watak tokoh memunculkan aneka ragam warna antawecana, seperti suara lantang untuk tokoh berwatak keras; suara licik untuk tokoh berwatak licik; suara halus untuk tokoh berwatak halus; suara kasar untuk tokoh berwatak kasar dan sebagainya. Mengenai suasana hati tokoh juga tercermin dalam ekspresi dialog tokoh wayang. Tokoh sedang marah memiliki ekspresi suara keras, kasar, meninggi; tokoh gembira diekspresikan dengan suara bersemangat, nyaring, tawa dan sebagainya. Ekspresi dialog yang berhubungan dengan persoalan yang dibicarakan menunjukkan adanya intensitas perbincangan, debat, adu argumen, pemberian solusi bagi masalah yang dihadapi.

Pengekspresian narasi tokoh ataupun narasi peristiwa dalam pertunjukan wayang mempertimbangkan situasi batin tokoh dan suasana adegan. Suasana sedih pada tokoh ataupun peristiwa adegan diekspresikan dengan pilihan kata tertentu yang mampu menunjukkan suasana sedih; diantawecanakan dengan warna suara yang mampu membangkitkan suasana hati dan peristiwa kesedihan; dan ekspresi dalang dengan membayangkan dan merasakan kondisi batiniahnya dalam kesedihan.

Konsep estetika antawecana tokoh wayang dan pencandraan suasana mengikuti konsep mungguh yaitu selaras antara tokoh atau suasana dengan ekspresi suara dalang. Harmonisasi antara tokoh dengan suaranya akan memberikan bobot estetik bagi penyajian pertunjukan wayang perjuangan. Dalam hal ini dikenal antawecana tokoh Jendral Soedirman, Soekarno, Moh. Hatta, Jenderal Spoor, Bu Dirman, Cokro Pranolo dan lain sebagainya. Antawecana menunjukkan watak dan tabiat serta suasana hati tokoh wayang perjuangan serta suasana adegan yang disajikan. Dalam hal ini warna suara orang Belanda berbeda dengan orang Indonesia.

Penyusunan antawecana tokoh dan peristiwa mengacu pada kejadian senyatanya pada masa perang gerilya. Suasana pegunungan yang damai, suasana perang yang mencekam, suasana kesedihan para tentara karena sang jenderal sakit, dan sebagainya dapat tergambarkan dengan hidup dan menjiwai melalui antawecana yang dilakukan dalang. Antawecana tokoh Jenderal Soedirman yang agung, mantap, dan lembut memberikan gambaran watak dan perangai serta sikap dari sang jenderal sebagai pejuang bangsa Indonesia.

Penyampaian antawecana wayang dengan menggunakan bahasa Indonesia dengan maksud agar dapat dipahami masyarakat Indonesia secara umum. Penggunaan bahasa Indonesia memberikan ruang terbuka kepada generasi muda untuk dapat mengapresiasi pertunjukan wayang perjuangan. Tujuan utama pendidikan bela negara bagi masyarakat juga dapat dipermudah dengan penggunaan bahasa pengantar bahasa Indonesia.

Sumber inspirasi antawecana wayang perjuangan dari berbagai buku, surat, dan ucapan yang pernah dilakukan oleh Jendral Soedirman. Beberapa petuah Jenderal Soedirman yang memberikan inspirasi penyusunan antawecana wayang perjuangan di antaranya sebagai berikut.

Pidato komando Panglima Besar Jenderal Soedirman setelah berlakunya undang-undang keadaan bahaya buat seluruh Jawa dan Madura: “Anak-anakku, sekalian tentara kepada seluruh anggota barisan-barisan dan lasykar lasykar yang bersama-sama kita merelakan segala-galanya guna kepentingan nusa, bangsa, dan agama kita: (1) percaya kepada diri sendiri, jangan gendaknya menantikan pertolongan dan bantuan dari luar negeri; (2) teruskan perjuangan sekarang ini, hendaknya jangan ada di antara kita yang kandas di tengah jalan; (3) pertahankan dengan segenap tenaga pekarangan dan rumah kita, rebut kembali apa-apa yang sudah di tangan musuh: (4) jangan ada di antara kita yang mempunyai sifat menyerah, menyerah berarti berkhianat terhadap saudara dan kawan kita yang dengan ikhlas sudah mengorbankan jiwanya guna kepentingan tanah air kita; (5) tunduk lahir dan batin kepada disiplin tentara".

\section{WAYANG PERJUANGAN SEBAGAI PENGUATAN PENDIDIKAN BELA NEGARA}

Kehadiran pertunjukan wayang memiliki beragam fungsi bagi masyarakat pendukungnya. Dalam berbagai diskusi mengenai fungsi wayang bagi masyarakat seringkali dikaitkan sesuai gradasinya, yakni fungsi tontonan, tuntunan, dan tatanan. Wayang sebagai tontonan dimaknai bahwa kehadiran pertunjukan wayang memberikan hiburan segar bagi para penontonnya. Pada tahapan berikutnya, fungsi wayang dapat menjadi tuntunan yang diartikan bahwa wayang dapat dijadikan sebagai wahana yang menuntun penontonnya pada pelajaran-pelajaran kehidupan yang penting. Pada akhirnya, wayang didudukkan sebagai tatanan yang dimaknai bahwa wayang dianggap sebagai salah satu norma bagi masyarakat dalam menata hidup dan kehidupannya. Ketiga fungsi ini satu sama lain saling berkaitan sehingga mengukuhkan kehadiran wayang sebagai pemuas kebutuhan jasmaniah maupun rohaniah, bahkan mampu memberikan suri tauladan mengenai norma ke- 

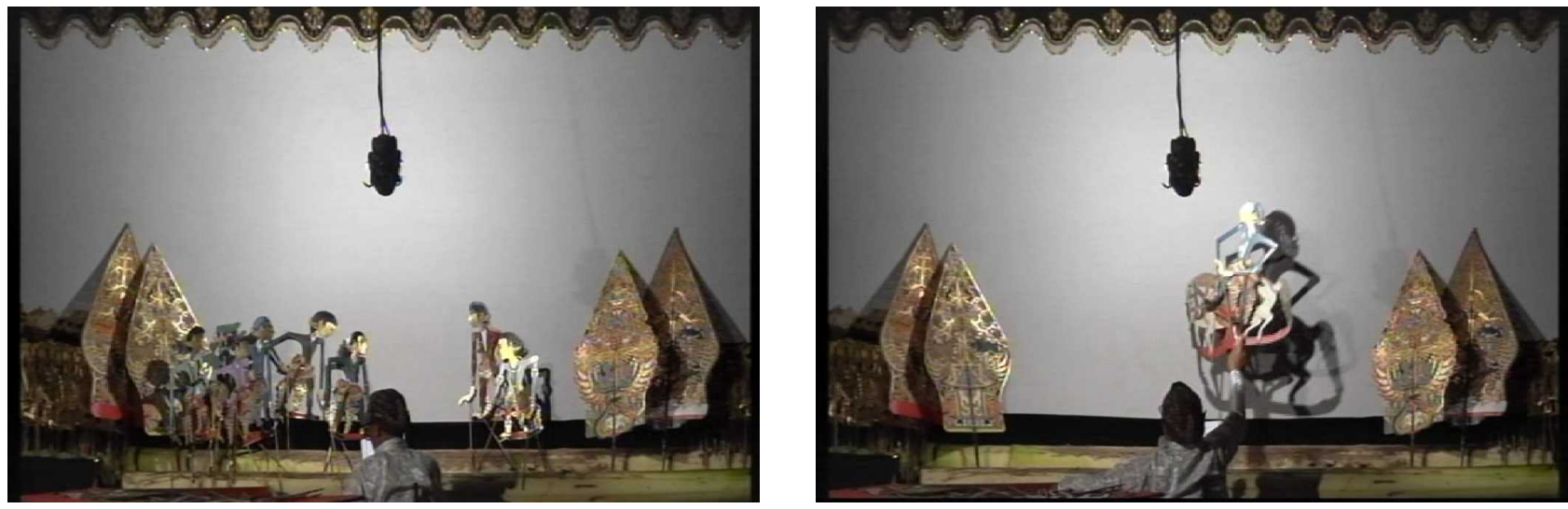

Gambar 3. Adegan Paseban Jawi: Jenderal Soedirman memerintahkan perang gerilya kepada TNI (sumber: Sunardi, 2017)

hidupan manusia.

Dalam tulisannya mengenai pertunjukan wayang, Soetarno (1998) mengemukakan beberapa fungsi yang melekat yaitu: (1) fungsi penghayatan estetis; (2) fungsi hiburan; (3) fungsi komunikasi; (4) fungsi sebagai ungkapan jatidiri; (5) fungsi berkaitan dengan norma sosial; (6) fungsi pengesahan lembaga sosial dan ritus keagamaan; (7) fungsi sebagai sarana pendidikan; (8) fungsi pengintegrasian masyarakat; (9) fungsi kesinambungan kebudayaan; dan (10) fungsi sebagai lambang penuh makna dan mengandung kekuatan. Sarwanto (2007) menambahkan fungsi pertunjukan sebagai sarana upacara dan sebagai hiburan pribadi. Di sini nampak bahwa wayang memiliki andil yang begitu besar dalam tata kehidupan masyarakat pendukungnya. Pertunjukan wayang menjadi model yang kompleks bagi tata hubungan manusia dengan Tuhan, dengan sesama, dan dengan jagad raya. Salah satu fungsi pertunjukan wayang yakni sebagai sarana pendidikan sangat menarik untuk mendapatkan perhatian.

Pertunjukan wayang perjuangan difungsikan sebagai wahana pengajaran pendidikan bela negara bagi masyarakat Indonesia. Dalam pertunjukan wayang ini dapat diperlihatkan muatan bela negara, seperti tokoh-tokoh wayang yang tampil, cerita yang disajikan, serta musik pengiringnya. Figur boneka wayang sebagai representasi dari para pejuang bangsa menstimuli masyarakat untuk meneladani sepak terjang mereka dalam merebut dan mempertahankan kemerdekaan Indonesia. Nilai patriotisme dan nasionalisme tokoh pejuang dapat dijadikan spirit bagi masyarakat untuk ikut serta menggugah kesadaran mereka dalam berbangsa dan bernegara. Pada aspek cerita yang disajikan memiliki tema utama mengenai perjuangan itu sendiri. Cerita yang digelar menunjuk pada kekuatan tokoh ataupun peristiwa pada masa perjuangan. Cerita tentang Soedirman, Bung Tomo, Soekarno-Hatta, Bandung lautan api, Palagan Ambarawa, serangan umum, dan sebagainya menghadirkan nuansa bela negara yang signifikan untuk direnungkan dan diimplementasikan pada kehidupan dewasa ini. Satu hal urgen yang tak kalah penting yakni penyajian musik wayang perjuangan dengan nuansa rasa musikal yang bersemangat dapat memberikan sentuhan rasa kepada masyarakat Indonesia akan hakikat bela negara.

Seperti diketahui bahwa bela negara merupakan konsep yang disusun oleh perangkat perundangan dan elit petinggi negara mengenai patriotisme individu, kelompok, atau semua komponen negara dalam kerangka mempertahankan eksistensi negara. Dalam artian fisik, bela negara dimaknai sebagai cara mempertahankan bangsa dalam menghadapi serangan fisik atau agresi dari pihak yang mengancam ketahanan negara. Pada pemahaman nonfisik, konsep bela negara diartikan sebagai upaya berperan aktif dalam memajukan bangsa dan negara melalui pendidikan, moral, maupun sosial. Pada intinya bela negara mengarahkan pada suatu masyarakat untuk menumbuhkan rasa nasionalisme sehingga mencintai bangsa dan negara Indonesia. Salah satu praktik bela negara dapat dilakukan dengan cara pengajaran nilai patriotisme melalui karya cipta pertunjukan wayang perjuangan.

Gambaran pendidikan bela negara bagi masyarakat diperlihatkan melalui pertunjukan wayang perjuangan lakon Gerilya Jenderal Soedirman. Beberapa tulisan mengenai Jenderal Soedirman (Imran, 1976; Soekanto S.A, 1981; Soewarno, 1985; Tim Buku Tempo, 2015) menjadi inspirasi utama lakon. Lakon ini berkisah mengenai perjuangan Panglima Besar Jenderal Soedirman dalam mengusir penjajah melalui perang gerilya. Petuah tentang bela negara dicermati melalui adegan-adegan yang disajikan dalam lakon sebagai berikut.

(1) Prolog, menceritakan peristiwa agresi militer Belanda dengan membombardir kota Yogyakarta, khususnya pangkalan udara TNI, Maguwo. Peristiwa ini membangkitkan kesadaran para pejuang bangsa yang dimotori Jenderal Soedirman untuk bersatu melakukan perlawanan terhadap Belanda. Keinginan Jenderal Soedirman mempertahankan negara dengan cara menemui Soekarno dan Hatta untuk melakukan perang gerilya. Semangat perjuangan dan rasa 
nasionalisme Jenderal Soedirman menjadi teladan bagi para pejuang bangsa Indonesia.

(2) Adegan Istana Negara Yogyakarta, menceritakan adu argumentasi dan penentuan sikap perjuangan antara Soedirman dengan Soekarno dan Hatta. Prinsip kuat dari Soedirman untuk mempertahankan negara melalui perang fisik dengan siasat perang gerilya menunjukkan besarnya rasa patriotisme yang dimilikinya. Adapun Soekarno dan Hatta memilih perjuanganya melalui meja perundingan. Prinsip bela negara yang diyakini Soedirman memberi petunjuk bahwa dirinya tokoh yang rela berkorban untuk bangsa dan negara yang dicintai.

(3) Adegan Keputren, mengisahkan Soedirman berpamitan kepada isterinya memberikan pelajaran berharga mengenai loyalitas kepada negara di atas kepentingan pribadinya. Pada sisi lain, terdapat contoh bela negara yang dilakukan seorang isteri tentara yang merelakan suaminya meninggalkan keluarga untuk berperang. Di sini jelas bahwa antara Pak Dirman dan Bu Dirman, keduanya memberikan suri tauladan kepada kita mengenai cinta tanah air dan rela berkorban.

(4) Adegan Paseban Jawi, menceritakan Soedirman meyakinkan kepada para pejuang lain untuk menempuh perang gerilya. Jiwa kepemimpinan Soedirman sangat menonjol dan didukung oleh para pejuang lainnya. Nilai bela negara yang dapat dipetik dari adegan ini adalah kuatnya rasa nasionalisme para tentara Indonesia di dalam mempertahankan ancaman dari Belanda. Kekuatan tentara dalam pengertian bela negara secara fisik dapat diwujudkan bersama-sama oleh para pejuangan bangsa.

(5) Adegan Sabrangan yang menceritakan usaha Belanda dan mata-mata Belanda untuk membuntuti gerakan Jenderal Soedirman memberikan pelajaran tentang sikap yang tidak perlu dicontoh dan harus dihindari oleh masyarakat, yakni sebagai penghianat bangsa. Para penghianat bangsa yang lebih mementingkan kesejahteraan individu memberi petunjuk mengenai rendahnya sikap mereka sebagai bagian dari bangsa Indonesia.

(6) Perang gagal menceritakan peperangan antara mata-mata Belanda melawan tentara pejuang menggambarkan dua pihak yang berseberangan faham. Para pejuang menunjukkan rasa nasionalisme yang tinggi berseberangan mata-mata Belanda yang telah menghianati bangsanya sendiri. Perlawanan sikap inilah yang menjadi pelajaran bagi masyarakat untuk menempatkan loyalitas pribadi kepada negara dan bukan menghianatinya.

(7) Adegan gara-gara, menarasikan perjalanan Soedirman naik gunung turun gunung di bawah ancaman Belanda, memberikan gambaran kegigihan Sang Jenderal dan para pejuang untuk mempertahankan negara. Pada adegan ini disajikan musik wayang perjuangan, terutama lagu-lagu perjuangan untuk membakar semangat para pejuang, yang menstimuli kepada masyarakat mengenai semangat perjuangan.

(8) Adegan Bajulan, mengisahkan penyamaran Jenderal Soedirman sebagai seorang Kyai yang mengajarkan ilmu agama. Taktik penyamaran Soedirman menjadi contoh kecerdasan seorang pejuang untuk mengecoh musuhnya. Kecerdasan Soedirman ini membuahkan hasil, karena Belanda segera meninggalkan dirinya dan para pejuang lain yang berarti telah menyelamatkan para pejuang bangsa. Taktik, siasat, ataupun strategi tentara harus dimiliki pejuang dengan mengandalkan daya kecerdasannya.

(9) Perang Kembang, mengisahkan tentara Belanda sedang membunuh mata-mata karena kecewa. Peristiwa terbunuhnya mata-mata yang tak lain adalah warga pribumi memberikan petunjuk kepada masyarakat mengenai penghianat yang mati tragis. Dalam hal ini, penghianatan menjadi sumber kebobrokan moralitas dan rendahnya rasa nasionalisme sebagai bangsa.

(10) Adegan Karangnongko, menceritakan Soedirman menderita sakit di tengah hutan di bawah kepungan tentara Belanda. Heru Kesser yang setia pada Soedirman melakukan penyamaran sebagai Jenderal Soedirman sehingga mampu mengecohkan tentara Belanda. Pada saat bersamaan Soedirman dilarikan para pengikutnya dengan cara ditandu. Adegan ini memberikan pelajaran kesetiaan dan kerjasama dalam perjuangan. Para pengikut dan pimpinannya saling melindungi sehingga terbebas dari bencana yang menghadangnya.

(11) Adegan Perjalanan, menceritakan Jenderal Soedirman ketika memutuskan kembali ke Yogyakarta. Pada saat melakukan perjalanan terjadi peperangan melawan Belanda. Perlawanan yang dilakukan Soedirman dan para pejuang lain menunjukkan sikap ksatria yang harus berani berkorban membela negaranya.

(12) Adegan Istana Negara, mengisahkan ketika Jenderal Soedirman menemui Soekarno dan Moh. Hatta untuk mewartakan perang gerilya. Pada adegan ini muncul kesadaran mengenai bela negara yang seharusnya dilakukan siapa saja yang mencintai tanah airnya. Sepak terjang Soedirman mendapatkan apresiasi tinggi dari pimpinan negara, Soekarno dan Hatta.

Atas dasar tokoh dan cerita tersebut dapat dinyatakan bahwa pertunjukan wayang perjuangan memiliki fungsi signifikan untuk pengajaran bela negara bagi masyarakat. Nilai-nilai bela negara yang bermuara pada tumbuhnya rasa patriotisme dan nasionalisme menjadi renungan mendalam bagi masyarakat Indonesia. Beberapa nilai bela negara dan pesan yang dapat dipetik dari cerita Gerilya Jenderal Soedirman pada pertunjukan wayang perjuangan ini adalah (1) kegigihan membela negara; (2) kecerdasan membela negara; (3) rela berkorban demi bangsa 
dan negara; (4) menjunjung tinggi kepentingan negara; (5) kepemimpinan yang tulus bagi negara; dan (6) janganlah menjadi penghianat bangsa dan negara sendiri.

\section{SIMPULAN}

Corak estetika pertunjukan wayang perjuangan diketahui dari beberapa elemen pembentuknya, yakni bentuk boneka wayang, lakon yang dipertunjukkan, dan teknik pertunjukannya. Ciri utama boneka wayang perjuangan terletak pada kebaharuan bentuknya yang merupakan perpaduan antara wajah manusia dan wayang purwa yang dilengkapi dengan ornamen dan asesoris tertentu. Adapun lakon yang dipergelarkan adalah lakon bertema perjuangan dengan mengangkat tokoh utama para pejuang bangsa Indonesia. Salah satu lakon yang dikreasi adalah Gerilya Jenderal Soedirman sebagai gambaran liku-liku perjuangan Panglima Besar Jenderal Soedirman dalam melawan penjajah Belanda. Pada desain dan teknik pemanggungan, tata lampu, dan tata suara memiliki perbedaan dengan wayang pada umumnya. Panggung dapat dikemas secara klasik ataupun eksperimental tergantung kebutuhan, demikian halnya dengan tata lampu dan tata suara. Dalang menempati posisi sentral sebagai pengendali jalannya pertunjukan wayang perjuangan.

Karya cipta pertunjukan wayang perjuangan memiliki fungsi utama sebagai penguatan nilai bela negara bagi masyarakat Indonesia. Pelajaran bela negara tercermin dari rangkaian lakon yang dipertunjukkan yakni suri tauladan Jenderal Soedirman dan para pejuang Indonesia dalam mempertahankan bangsa dan negara. Dengan mencermati dan meresapi cerita yang dipertunjukkan, masyarakat dapat mengambil pelajaran berharga yaitu cara mencintai bangsa dan negara. Atas dasar suri tauladan para pejuang bangsa Indonesia ini dapat menumbuhkan rasa patriotisme dan nasionalis yang bermuara pada rasa cinta terhadap nusa dan bangsa Indonesia. Disinilah pentingnya wayang perjuangan sebagai penguatan nilai bela negara bagi masyarakat Indonesia.

\section{DAFTAR RUJUKAN}

Haryanto, S. (1991), Seni Kriya Wayang Kulit: Seni Rupa, Tatahan, dan Sunggingan. Jakarta: Djambatan.

Haryono, Timbul. (2008), Seni Pertunjukan dan Seni Rupa dalam Perspektif Arkeologi Seni. Surakarta: ISI Press Solo.

Hazeu, G.A.J. (1979), Kawruh Asalipun Ringgit sarta Gegepokanipun Kaliyan Agami ing Jaman Kina. Ed. Mangkudimedjo, alih aksara oleh Sumarsana, alih bahasa oleh Hardjana HP, Proyek Penerbita Buku Bacaan dan Sastra Indonesia dan Daerah, Depdikbud, Jakarta.
Holt, Claire. (2000), Melacak Jejak Perkembangan Seni di Indonesia, Terjemahan R.M. Soedarsono, Bandung: Masyarakat Seni Pertunjukan Indonesia.

Imran, Amrin. (1976), Panglima Besar Jenderal Sudirman. Jakarta: Mutiara.

Jazuli, M. (2003), Dalang, Negara, Masyarakat: Sosiologi Pedalangan. Semarang: Limpad.

Mulyono, Sri. (1975), Wayang Asal-usul Filsafat dan Masa Depannya. Jakarta: Alda.

(1982), Wayang Asal-usul Filsafat dan Masa Depannya. Jakarta: Gunung Agung.

Murtiyoso, Bambang, Sumanto, Suyanto, Kuwato. (2007), Teori Pedalangan: Bungan Rampai Elemen-elemen Dasar Pakeliran. Surakarta: ISI Surakarta Press dan CV Saka Production.

Nugroho, Sugeng. (2012), Lakon Banjaran Tabir dan Liku-likunya Wayang Kulit Purwa Gaya Surakarta. Surakarta: ISI Press.

Parker, De Witt H. (1948), The Principles of Aesthetics. New York: Appleton Century Crofts.

Sarwanto. (2008), Pertunjukan Wayang Kulit Purwa dalam Ritual Bersih Desa Kajian Fungsi dan Makna. Surakarta: ISI Press Surakarta dan CV Cendrawasih.

Soekanto S.A. (1981), Perjalanan Bersahaja Jenderal Sudirman. Jakarta: Pustaka Jaya.

Soetarno. (1998), "Fungsi Sosial Pertunjukan Wayang Kulit Purwa Jawa”. Laporan Penelitian STSI Surakarta.

Soetarno, Sarwanto, Sudarko. (2007), Sejarah Pedalangan. Surakarta: ISI Press Surakarta dan CV Cendrawasih.

Soewarno, Roto. (1985), Pak Dirman Menuju Sobo. Jakarta: Yayasan Kembang Mas.

Sunardi. (2014), Nuksma dan Munguh Konsep Dasar Estetika Pertunjukan Wayang. Surakarta: ISI Press.

Sunardi, Sugeng Nugroho, Kuwato. (2016), Wayang Babad Nusantara Media Pengajaran Nilai Kebangsaan. Surakarta: ISI Press.

Tim Buku Tempo. (2015), Soedirman: Seorang Panglima, Seorang Martir. Jakarta: Gramedia.

Waridi. (2005), Karawitan Wayang Kulit Purwa Gaya Surakarta. Jakarta: Senawangi. 